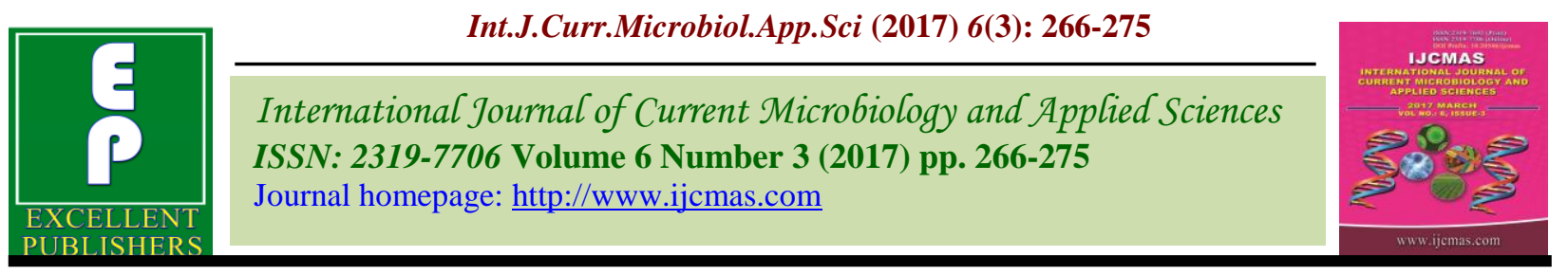

Original Research Article https://doi.org/10.20546/ijcmas.2017.603.029

\title{
Studies on Emasculation and Pollination in Underutilized Legume-Bambara Groundnut- (Vigna subterranea (L.) Verdc.)
}

\author{
Kailash Chandra $^{1}$, R. Nandini ${ }^{2}$, R. Gobu ${ }^{1}$, Pranesh $^{3}$ and Chitti Bharat Kumar ${ }^{4}$ \\ ${ }^{1}$ Department of Genetics and Plant Breeding, Institute of Agricultural Sciences, \\ Banaras Hindu University, Varanasi-221005, India \\ ${ }^{2}$ GKVK Campus, University of Agricultural Sciences, Bengaluru-560065, India \\ ${ }^{3}$ Department of Genetics and Plant Breeding, University of Agricultural Sciences, \\ Bengaluru-560065, India \\ ${ }^{4}$ Indian Cardamom Research Institute, Mailadumpara, Kerala- 685554, India \\ *Corresponding author
}

\section{A B S T R A C T}

\begin{tabular}{|l|}
\hline K e y w o r d s \\
Flower biology, \\
Pollen viability, \\
Stigma receptivity, \\
Emasculation, \\
Anthesis.
\end{tabular}

\begin{abstract}
Understanding ancillary traits related to flower biology is crucial to understand the appropriate time for emasculation and pollination in order to achieve a successful cross to develop hybrids with high yield and other economically important traits. Being an underutilized crop, it has not received all the attention as received for other pulses, hence an investigation was carried out at University of Agricultural Sciences Bengaluru in kharif season of 2015 for the first time in India to study to standardize the time of emasculation and pollination of different varieties and mutants of variety SB-42. From this study, it was observed that the average interval between flower bud initiation and anthesis days was 4.75 days. Therefore flower buds intended for hybridization should be 2 days old from bud initiation. Pollination timing for making cross will play an important role in seed set so with this view pollen viability and stigma receptivity has been studied and found that best time for making cross is 1 a.m. to 3 a.m. The results of the present investigation explored the opportunities of utilizing information in order to develop hybrids with multiple desired characters.
\end{abstract}

\section{Introduction}

Grain legumes serve as a cheap source of protein to a large proportion of the population in poor countries of the tropics. To serve this purpose, Bambara groundnut (Vigna subterranean (L.) Verdc), an indigenous African legume, plays an important socioeconomic role in the semi-arid regions of Africa (Massawe et al., 2005). Many people might be confuse that Bambara groundnut is a cultivar of groundnut, but it is an underutilized legume crop known for high protein content. However this crop is still at the research platform not cultivated commercially in India. It is extensively cultivated in Africa as it is the third important legume crop followed by groundnut and cow pea. The seed makes a complete food, as it contains sufficient quantities of proteins, carbohydrates and lipid (Brough and AzamAli, 1992; Brough et al., 1993). It is a popular crop because of its resistance to drought and the ability to produce a reasonable crop when 
grown on poor soils. However, it has low status as it is seen as a snack or food supplement but not a lucrative cash crop. It is necessary to produce genetically pure and good quality seeds by adopting suitable seed production techniques. The use of $\mathrm{F}_{1}$ hybrids is one of the means to meet ever increasing demand, as $F_{1}$ hybrids offer several advantages such as higher productivity, improved quality, resistance to biotic and abiotic stresses etc. and also provide a quick and convenient way of combining desirable characters (Kivadasannavar et al., 2009). The role of gametophytic phase is mostly neglected and if any, its role is passively exploited in breeding methods (Chandra et al., 2016). In the absence of suitable information regarding the time of emasculation and pollination, it became impossible to proceed for hybridization. Hence, there is a need to standardize the techniques like suitable time of emasculation and pollination in Bambara groundnut.

This need is also realized by Goli, 1997 as at IITA crosses made was unsuccessful due to not having the knowledge of proper time of emasculation and pollination and several other authors also reported the same problem in terms of getting crossed seed (Massawe et al., 2003; Khattak et al., 1998) that also might be due to incompatibility between pollen viability and stigma receptivity or emasculation timing. Varieties developed till now are a selection from existing germplasm whereas, poor Bambara groundnut farmer in Africa and cultivating countries are in hope that they will get the genotype with multiple desired character like disease resistance, early maturity and high yielding. No doubt this improvement will make this crop suitable to Indian condition also to bring it from research trial to farmer field. Hence the objective of the present study was to identify the suitable time for of emasculation and pollination in Bambara groundnut.

\section{Materials and Methods}

The present study was carried out at K-block, agriculture farm of University of agriculture Sciences, Gandhi Krishi Vignana Kendra, Bengaluru during kharif season of 2014-15, geographically, the place is located at $12^{\circ} 58^{\prime}$ latitude north and $77^{\circ} 35^{\prime}$ longitude east. The center is at an altitude of 930 meters above sea level. The annual rainfall ranges from $679.1 \mathrm{~mm}$ to $888.9 \mathrm{~mm}$. Bambara groundnut varieties SB-42, Uniswa Red, S-165-A, and S-193 were used for present investigation. The seeds were obtained from National Research Centre on Groundnut, Junagadh through National Bureau of Plant Genetic Resources. Seeds were sown in two replication with spacing of $30 \mathrm{~cm}$ between rows and $15 \mathrm{~cm}$ between plant to plant within a row. N: P: K fertilizers dose of 25:75:38 kg per hectare applied. Suitable management practices were undertaken during the period of the crop (Figure 1, 2).

In the present study, effect of variation was studied in the form of the mean, range, coefficient of variance and critical difference value for days to flower bud initiation, days to anthesis and days to fifty $\%$ flowering.

To find out the suitable time for emasculation and pollination pollen viability and stigma receptivity also observed by using following suitable protocol.

\section{Pollen viability (Lyra et al., 2011)}

Pollen viability was determined using 1 percent acetocarmine staining technique. Pollen grains were collected from 5 flowers of one hour time intervals at 12 midnight, 1 a.m., 2 a.m., 3 a.m., 4 a.m., 5 a.m., 6 a.m., 7 a.m., 8 a.m., 9 a.m., 10 a.m., 11 a.m., 12 noon, 1 p.m., 2 p.m., 3 p.m., 4 p.m., 5 p.m., 6 p.m., 7 p.m., 8 p.m., 9 p.m., 10 p.m. and 11 p.m. The pollen was collected with a sterile brush and 
submerged in test tubes containing acetic carmine. Soon after each collection period, five slides per sample were prepared and pollen grains were counted at random per slide using a fluorescence microscope. Red colored pollen grains were considered viable and non-colored pollen grains were considered non-viable.

\section{Receptiveness of the stigma (Dafni, 1992)}

Flowers were randomly collected during anthesis of SB-42 variety and studied for receptiveness of stigma. one hour time intervals at 12 midnight, 1 a.m., 2 a.m., 3 a.m., 4 a.m., 5 a.m., 6 a.m., 7 a.m., 8 a.m., 9 a.m., 10 a.m., 11 a.m., 12 noon, 1 p.m., 2 p.m., 3 p.m., 4 p.m., 5 p.m., 6 p.m., 7 p.m., 8 p.m., 9 p.m., 10 p.m. and 11 p.m. The entire female reproductive organ (stigma, style and ovary) was dissected and kept on slides and two-three drops of hydrogen peroxide (3\%) were put on stigmatic papillae in order to verify peroxidase activity and the release of air bubble on stigmatic papillae indicating receptiveness of the stigma to pollen grains.

\section{Results and Discussion}

The success in crop improvement of Bambara groundnut depends on the ability of a breeder to define and assemble the required genetic variability and to select for yield indirectly through yield associated characters. Results for optimizing the time for emasculation and pollination explained under the following heading.

\section{Days to flower bud initiation and days to anthesis}

Improvement of Bambara groundnut has been largely difficult due to the autogamous nature of the crop. Understanding appropriate time for emasculation is crucial in order to achieve a successful cross. From this study, it was observed that the average interval between flower bud initiation and anthesis days was 4.75 days. Hence on an average, it took between 4.75 days for initiated flower buds to mature and open. Therefore flower buds intended for hybridization should be 2 days old from bud initiation. Furthermore, emasculation should be carried out on mature flower buds within these days. A similar result obtained with the study from Onwubiko et al., 2011 in Bambara groundnut stating that the initiation of flower buds was between 30 and 48 days after planting while the maturity of the flowers was between 34 and 52 days after planting (3 to 5 days from flower bud initiation). Matured flowers for hybridization should be 2 to 3 days old from bud initiation.

Bambara groundnut genotype took 53.69 mean days for anthesis, hence a breeder, if he is interested in hybridization then before anthesis invariably he has to go for emasculation because, in self-pollinated crops where the flower is cleistogamous, pollination occur before flower opening. It was observed that the mean values for days to anthesis decreased when compared to control SB-42. The Wider range was observed for days to anthesis (49.90-62.80 days). Days to $50 \%$ flowering was related to emergence pattern. It was found that generally, SB-42 flower in 53.60 to 57.25 days after sowing. The remaining three varieties flowered 62.35 to 68.05 days after sowing (Table 1). This may be a varietal characteristic, since these flowered late than the SB-42. During flowering period temperature ranged from $18.8^{\circ} \mathrm{C}$ to $28.1^{\circ} \mathrm{C}$, relative humidity was 56 per cent to 94 per cent and rainfall of 428.4 $\mathrm{mm}$ during the time of the experiment there was a reduction in temperature and increase in relative humidity due to heavy rainfall (Table 3 ). This might have influenced the flowering date. Kumaga et al., (2002) had stated that rainfall and temperature appeared to be the two most important climatic factors that influence vegetative growth, flowering and yield of Bambara groundnut. 
Table.1 Mean value of few traits relation to emasculation of different varieties and mutants of Bambara groundnut

\begin{tabular}{|l|l|c|c|c|}
\hline Sl. No. & Genotypes & $\begin{array}{c}\text { Days to flower bud } \\
\text { initiation }\end{array}$ & $\begin{array}{c}\text { Days to } \\
\text { anthesis }\end{array}$ & $\begin{array}{c}\text { Days to 50\% } \\
\text { flowering }\end{array}$ \\
\hline 1 & SB-42 & 48.60 & 52.70 & 55.70 \\
\hline 2 & Uniswa Red & 53.80 & 57.60 & 62.35 \\
\hline 3 & S-165 A & 54.65 & 59.70 & 65.15 \\
\hline 4 & S-193 & 56.30 & 62.80 & 68.05 \\
\hline 5 & Mutant 1 & 46.40 & 49.90 & 53.60 \\
\hline 6 & Mutant 2 & 46.30 & 51.00 & 54.80 \\
\hline 7 & Mutant 4 & 47.10 & 52.40 & 56.10 \\
\hline 8 & Mutant 6 & 46.20 & 50.60 & 55.70 \\
\hline 9 & Mutant 8 & 48.10 & 53.60 & 58.80 \\
\hline 10 & Mutant 11 & 47.90 & 51.80 & 56.90 \\
\hline 11 & Mutant 15 & 47.50 & 53.40 & 57.25 \\
\hline 12 & Mutant 19 & 47.10 & 51.70 & 55.70 \\
\hline 13 & Mutant 24 & 46.30 & 50.80 & 55.60 \\
\hline Minimum & 46.30 & 49.90 & 53.60 \\
\hline Maximum & 56.30 & 62.80 & 68.05 \\
\hline Mean & 48.94 & 53.69 & 58.13 \\
\hline C.V. & 2.69 & 1.36 & 1.23 \\
\hline C.D.(0.05) & 2.87 & 1.59 & 1.56 \\
\hline F test & $14.37 * *$ & $57.72 * *$ & $73.83 * *$ \\
\hline
\end{tabular}


Table.2 Pollen viability and stigma receptivity of SB-42 variety of Bambara groundnut

\begin{tabular}{|c|c|c|}
\hline Time of the day & Pollen viability (\%) & Stigma receptivity (\%) \\
\hline 1 p.m. & 51.50 & 30.00 \\
\hline 2 p.m. & 60.60 & 30.00 \\
\hline 3 p.m. & 70.00 & 40.00 \\
\hline 4 p.m. & 65.50 & 30.00 \\
\hline 5 p.m. & 66.28 & 20.00 \\
\hline 6 p.m. & 70.02 & 40.00 \\
\hline 7 p.m. & 69.23 & 50.00 \\
\hline 8 p.m. & 80.28 & 70.00 \\
\hline 9 p.m. & 75.22 & 70.00 \\
\hline 10 p.m. & 89.69 & 80.00 \\
\hline 11 p.m. & 84.12 & 90.00 \\
\hline 12 midnight & 93.76 & 90.00 \\
\hline 1 a.m. & 96.32 & 100.00 \\
\hline 2 a.m. & 94.22 & 100.00 \\
\hline 3 a.m. & 90.25 & 100.00 \\
\hline 4 a.m. & 80.09 & 90.00 \\
\hline 5 a.m. & 72.52 & 60.00 \\
\hline 6 a.m. & 61.52 & 40.00 \\
\hline 7 a.m. & 58.33 & 20.00 \\
\hline 8 a.m. & 56.22 & 10.00 \\
\hline 9 a.m. & 76.99 & 10.00 \\
\hline 10 a.m. & 73.70 & 20.00 \\
\hline 11 a.m. & 64.23 & 20.00 \\
\hline 12 Noon & 72.86 & 20.00 \\
\hline
\end{tabular}


Table.3 Climatic data during crop growth period (2014-2015) (Department of Agrometeorology, UAS, GKVK Bengaluru)

\begin{tabular}{|c|c|c|c|c|c|}
\hline \multirow[t]{2}{*}{ Month } & \multicolumn{2}{|c|}{ Temp. $\left({ }^{0} \mathrm{C}\right)$} & \multicolumn{2}{|c|}{ Relative humidity (\%) } & \multirow[t]{2}{*}{ Rainfall (mm) } \\
\hline & Max & Min & Max & Min & \\
\hline August & 28.2 & 19.5 & 93 & 56 & 117.4 \\
\hline September & 28.5 & 19.4 & 91 & 54 & 128.6 \\
\hline October & 28.1 & 18.8 & 94 & 56 & 428.4 \\
\hline November & 26.5 & 16.3 & 90 & 54 & 29.4 \\
\hline December & 26.6 & 16.2 & 90 & 48 & 1 \\
\hline January & 15.2 & 16.8 & 91 & 45 & 10 \\
\hline
\end{tabular}

Figure.1 Field view of Bambara groundnut

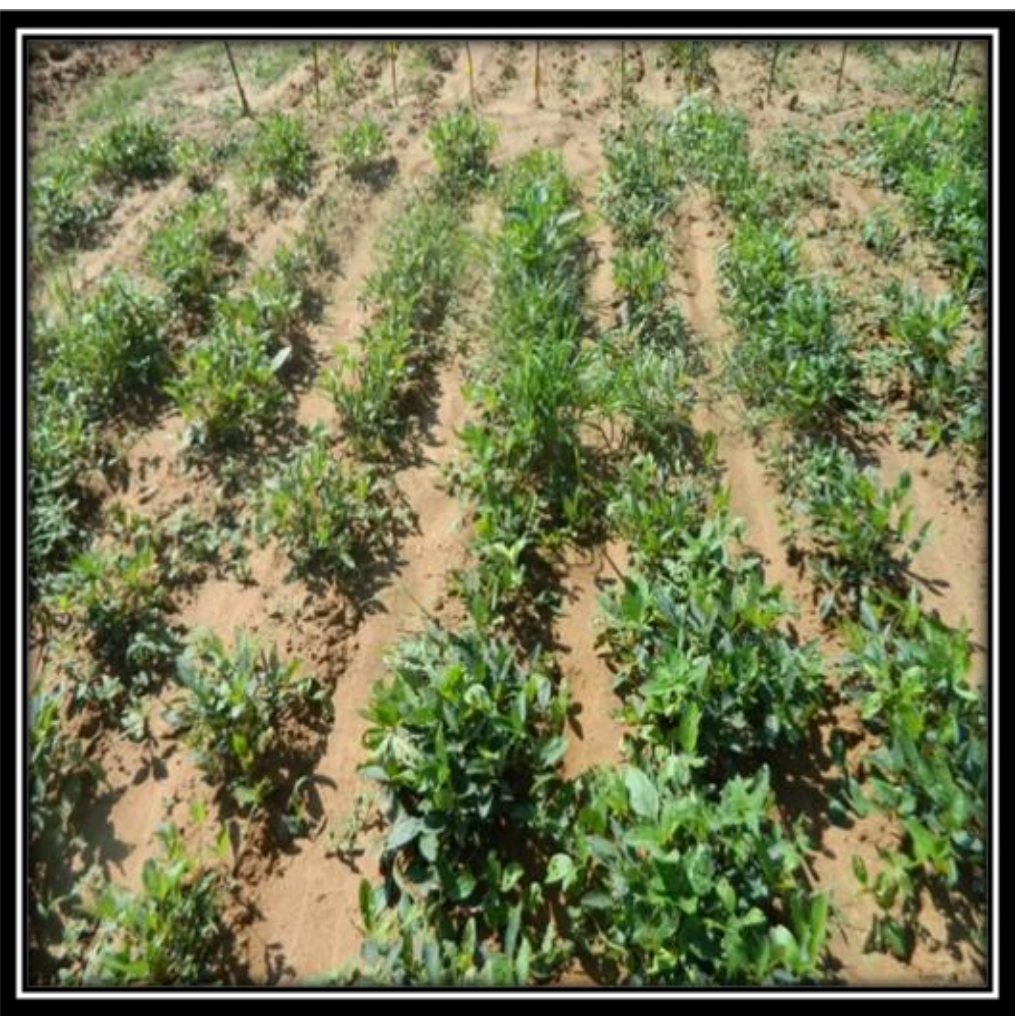


Int.J.Curr.Microbiol.App.Sci (2017) 6(3): 266-275

Figure.2 Bambara groundnut plant

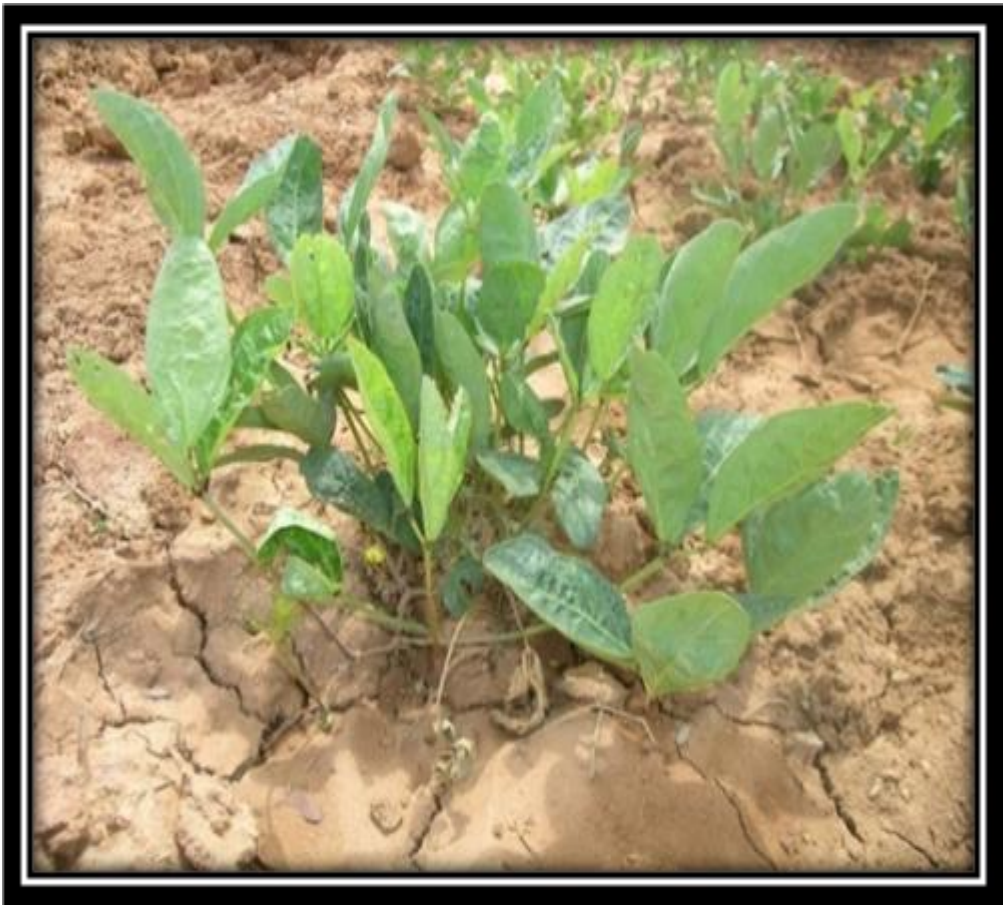

Figure.3 Maximum pollen viability of SB-42 at 1 a.m

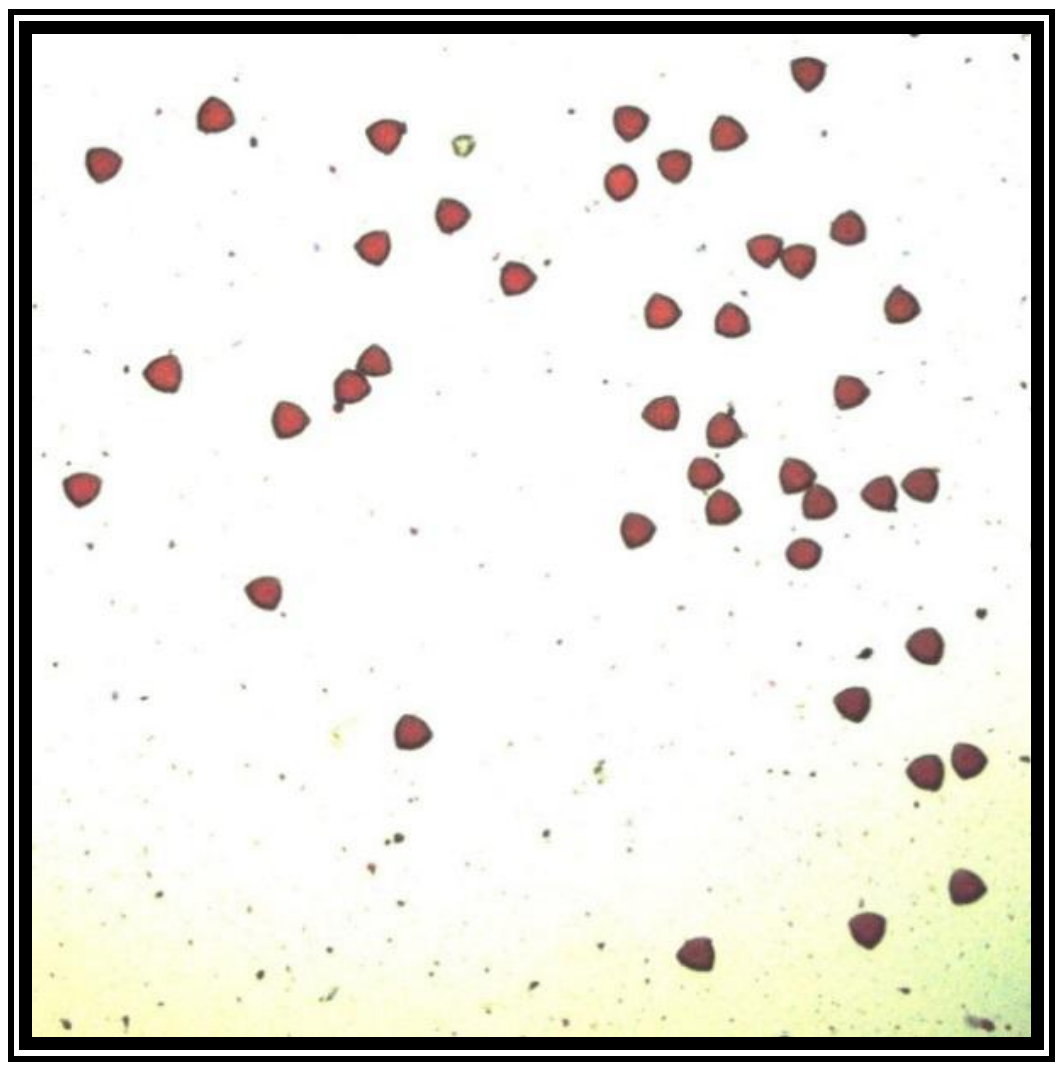


Figure.4 Minimum pollen viability of SB-42 at 1 p.m

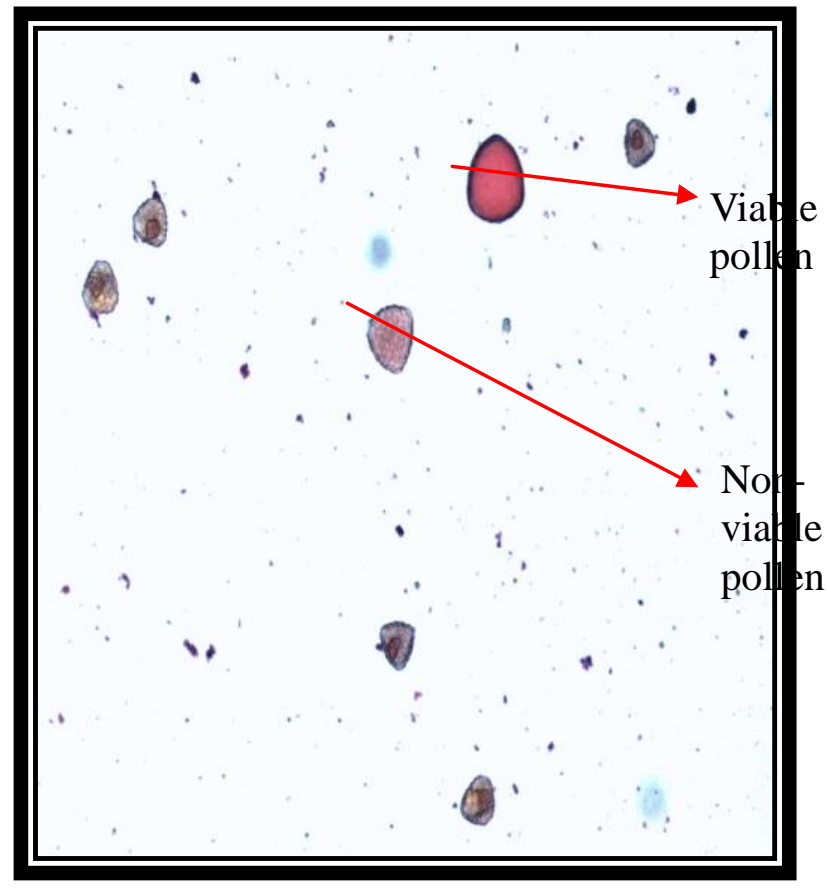

Figure.5 Peroxidase activity on Vigna subterranea stigma indicating receptiveness by liberating air bubbles

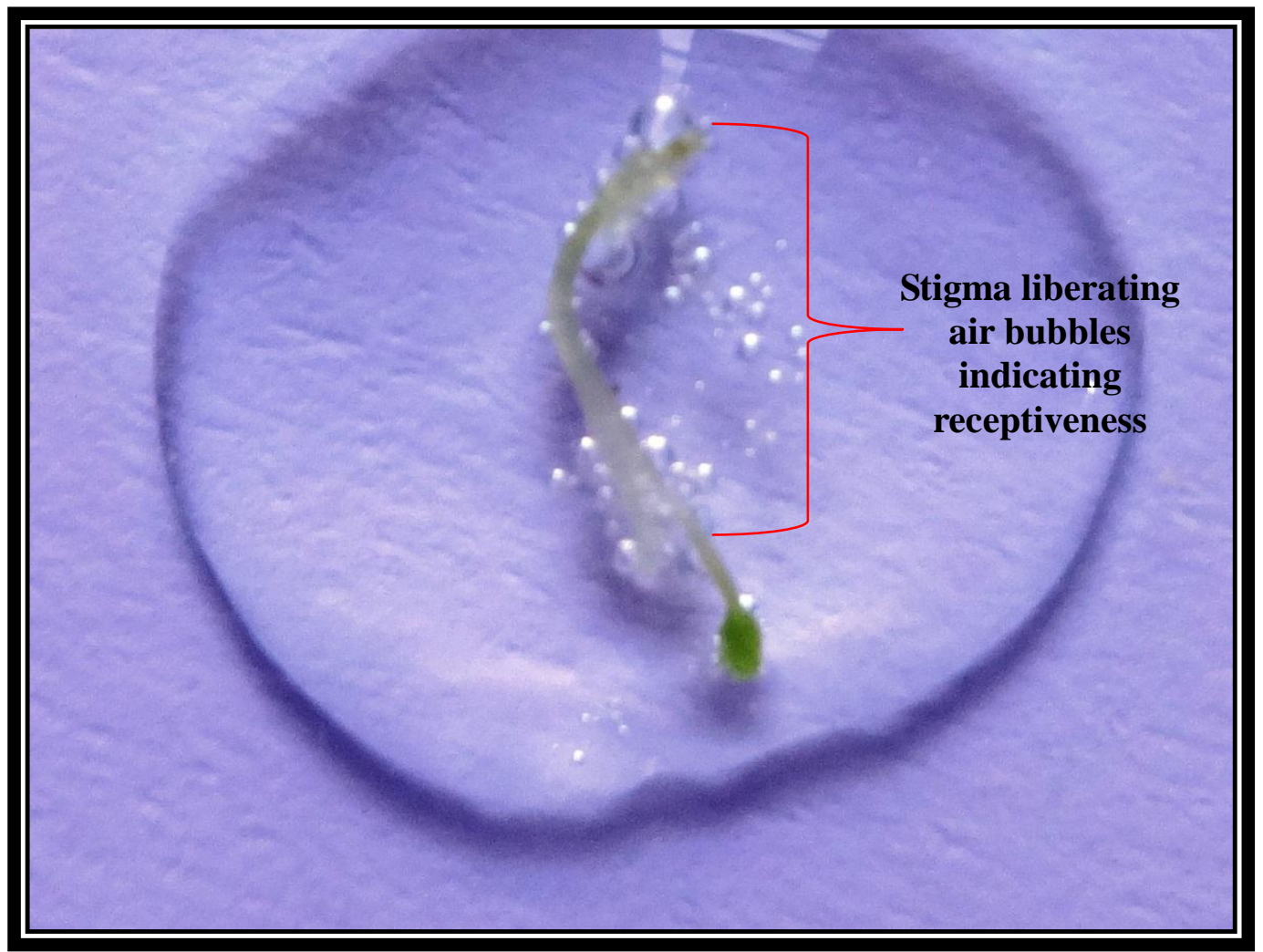




\section{Pollen viability and stigma receptivity}

As an underutilized crop Bambara groundnut has not received focused research reports on pollen viability and stigma receptivity has not been attempted in this crop. Since SB-42 variety is an adapted variety to the semi-arid tracts of Karnataka, this material has been used for the present investigation to study the pollen viability and stigma receptivity.

Pollen is an important vector of gene flow in plants. Investigation on pollen viability and stigma receptivity indicated that maximum pollen viability was at the time period of 12 midnight to 3 a.m., whereas hundred per cent stigma receptivity has been observed in the time period of $1 \mathrm{a}$ a.m. to $3 \mathrm{a}$ a.m. (Table 2). This information can be exploited for hybridization programme in which crossing will be successful if it is done in the period of 1 a.m. to 3 p.m. Since pollen as well as stigma receptivity both is maximum (Figure 3, 4 and $5)$.

In conclusion, emasculation and pollination are an important technique which will determine the success rate of crossed seed set, with this background it has been found that Bambara groundnut genotypes took 4.75 days for initiated flower buds to mature and open. They took 48.94 days to flower bud initiation and 53.69 days to anthesis. Therefore flower buds intended for hybridization should be 2 days old from bud initiation. Because Bambara groundnut has a cleistogamous flower, pollination will occur before the flower opens. In order to avoid this in crossing programme, two days after flower bud initiation the mature flowers buds have to be emasculated.

Pollination is the process by which pollen is transferred from the anther (male part) to the stigma (female part) of the plant, thereby enabling fertilization and reproduction.
Pollination timing for making cross will play an important role in seed set so with this view pollen viability and stigma receptivity has been studied and found that best time for making cross is 1 a.m. to 3 a.m. since during this period of time pollen viability and stigma receptivity is maximum and, hence possibility of getting maximum number of crossed seed is more.

\section{Acknowledgement}

It's my greatest privilege to express my profuse and deepest sense of gratitude to Professor Balkrishna Gowda for his valuable technical guidance, continued cooperation and advice throughout the experiment period. I express my sincere gratitude to Professor K.M. Harinikumar, Department of Plant Biotechnology, University of Agricultural Sciences, Bengaluru for providing fluorescent microscope and other lab facility. I am highly indebted to Mr. Swapnilkumar who helped me a lot during research.

\section{References}

Brough, S.H., Taylo, A.J. and Azam-Ali, S.N. 1993. The potential of bambara groundnut (Vigna subterranea) in vegetable milk production and basic protein functionality systems. Food Chem., 47: 277-283.

Chandra, K., Nandini, R., Gobu, R., Muthuraju, R., Bharatkumar, C. and Pranesh. 2016. In-vitro study of pollen tube length and pollen germination of underutilized legume-Bambara groundnut (Vigna subterranea $(\mathrm{L}$.) Verdc.) Eco. Env. and Cons., 22 (September Suppl.) S209-S213.

Dafni, A. 1992. Pollination ecology: a practical approach. Oxford University Press, Oxford.

Goli, A.E. 1997. Bibliographical review. In: J. Heller, F. Begemann and J. Mushonga, 
(Eds.), Proceedings of the Workshop on Conservation and Improvement of Bambara Groundnut (Vigna subterranea (L.) Verdc.), 14-16 November 1995, Harare, Zimbabwe. Institute of Plant Genetics and Crop Plant Research, Gatersleben, Department of Research and Specialist Services, Harare and International Plant Genetic Resources Institute, Rome, Italy.

Khattak, G.S.S., M.A. Hag, S.A. Rana, T.Elahi and P. Srinives. 1998. An efficient technique for crossing mungbean (Vigna radiata (L.) Wilczek). Thai J. Agric. Sci., 31: 577Lyra, D.H., Sampaio, L.S., Pereira, D.A., Silva, A.P. and Amaral, C.L. 2011. Pollen viability and germination in Jatropha mollissima (Euphorbiaceae): Species with potential for biofuel production. Afr. J. Biotechnol., 10(3): 368-374.

Massawe, F.J., Mwale, S.S., Azam-Ali, S.N. and Roberts, J.A. 2005. Breeding in Bambara groundnut (Vigna subterranea (L.) Verdc.): strategic considerations. African J. Biotechnol., Vol. 4(6): 463-471.

Massawe, F.J., Roberts, J.A., AZam-Ali,
582.

Kivadasannavar, P., Deshpande, V.K., Vyakaranahal, B.S., Mohankumar, H.D., Biradar, D.P. and Nadaf, H.L. 2009. Studies on emasculation and pollination in hybrid seed production of chilli (Capsicum annuum L.) Karnataka J. Agric. Sci., 22(2): (301-305).

Kumaga, F.K., Ofori, K. and Coblavi, C.S. 2002. Effect of time of planting on growth, flowering and seed yield of Bambara groundnut (Vigna subterranean (L)Verdc.). Begemann F., I. Mukema and E. Obed - Lawson, (eds.). $\quad$ pp. $60 \quad-\quad 65$.

S.N. and Davey, M.R. 2003. Genetic diversity in bambara groundnut (Vigna subterranea (L.) Verdc.) Landraces assessed by Random Amplified Polymorphic DNA (RAPD) markers. Genet. Resour. Crop Evol., 50: 737741.

Onwubiko, N.C., Uguru, A.A., Ngwuta, E.T., Inyang, and Nnajiemer, E.O.J. 2011. Floral biology of Bambara groundnut [Vigna subterranean (L.)Verdc], J. Plant Breed. and Crop Sci., 3(11): 293-295.

\section{How to cite this article:}

Kailash Chandra, R. Nandini, R. Gobu, Pranesh and Chitti Bharat Kumar. 2017. Studies on Emasculation and Pollination in Underutilized Legume-Bambara Groundnut- (Vigna subterranea (L.)Verdc.). Int.J.Curr.Microbiol.App.Sci. 6(3): 266-275. doi: https://doi.org/10.20546/ijcmas.2017.603.029 